\title{
The Effectiveness of Comic as Learning Media to Enhance Knowledge of Menarche and Menstruation among Female Students in Yogyakarta
}

\author{
Annisa Nuraini, Sudarto Ronoatmodjo \\ Faculty of Public Health, Universitas Indonesia
}

\begin{abstract}
Background: Menarche and menstruation are physiological process but they can cause physical, emotional discomfort, and anxiety. Menarche age tends to decline. Ignorance about menarche and menstruation may increase the risk of early pregnancy or unwanted pregnancy. This study aimed to determine the effectiveness of comic as a learning media to enhance knowledge on menarche and menstruation among female primary school students in Yogyakarta.

Subjects and Method: This was a quasi-experiment with before and after study along with control group design conducted at Muhammadiyah primary schools in Sagan and Kauman, Yogyakarta, from October to November 2016. The sample of this study was 90 female students of primary school. The dependent variable was knowledge of menarche and menstruation. The independent variable was learning media (comic versus leaflet). The data were collected through questionnaire. The data were analyzed by Mann-Whitney test.

Results: The increase in knowledge scores after intervention in the comic group $(\mathrm{mean}=53.30)$ was higher than leaflet group (mean $=38.04)$, and it was statistically significant $(\mathrm{p}=0.005)$.

Conclusion: Comic is more effective as learning media than leaflet in enhancing knowledge of menarche and menstruation among primary school students.
\end{abstract}

Keywords: menarche, menstruation, comic, leaflet, learning media

Correspondence:

Annisa Nuraini. Faculty of Public Health, Universitas Indonesia, Jl. Prof. Dr. Sujudi, Pondok Cina, Beji, Depok, West Java. Email: aninisaa.nuraini@gmail.com. Mobile: 085758919474.

\section{BACKGROUND}

Human growth and development went through several phases, one of them is adolescence (Wiknjosastro, 2006). According to WHO, people can be said as adolescence if they are 10-19 years old (WHO, 2011). In adolescence, physical and sexual growth began to develop rapidly. This is a biological sign of sexual maturity. These changes occur in puberty where this period is a transition from childhood to reproduction (Wiknjosastro, 2006). According to population projection data in 2015, the adolescent population occupies a significant amount in the population structure, which is around 66 million people or $25 \%$ of the population in Indonesia. Based on data from the DIY
Central Bureau of Statistics, the number of adolescents in 2016 is estimated to reach 205.5/1,000 people (Central Statistics Agency, 2015).

In female adolescent, puberty is characterized by the emergence of physical and psychological changes and important events, which is the first menstruation called menarche (Kartono, 2006). Menstruation is the time of the collapse of the endometrial wall in the uterus because fertilization does not occur. The first menstruation (menarche) is the most important sign for the development of young women and as andication that their reproductive system is mature, complete, and ready to function (Prawirohardjo, 2005). In Indonesia, the first menstruation in adolescents 
Journal of Health Promotion and Behavior (2018), 3(4): 257-262

https://doi.org/10.26911/thejhpb.2018.03.04.05

varies between the ages of 10-16 years old and the average age of menarche is 12.5 years old. The age of menarche of female adolescent in DIY was 11.69 years old (Central Statistics Agency, 2015). Data from the Ministry of Education and Culture of the Republic of Indonesia showed that elementary school students start from the age of 7-12 years old (BKKBN, 2012).

Menarche and menstruation are physiological processes but cause physical discomfort and effects on emotional, social, hygiene and can cause anxiety. Menarche and menstruation are embarrassing and hidden in the social environment and school environment and there are those who think that menstruation is a disease even though the occurrence of menstruation is normal in women. A girl who experiences menarche can be confused, restless and uncomfortable (Sally, 2005). There are $85 \%$ of female adolescents felt embarrassed and disturbed (Proverawati and Misaroh, 2017). From the results of a study by Ozdemir et al. (2011), the adolescent's response to menarche was $37.6 \%$ of teenagers were afraid, $33 \%$ were embarrassed, $19.1 \%$ were surprised, and only $9.8 \%$ felt happy.

Various views and negative feelings about menstruation occurred because not all girls get information about menstrual processes and health during menstruation so they cannot make enough preparation to recognize and face the menstruation (Wahyudi, 2001). The results of in-depth interviews conducted by Wulandari in adolescent girls in Purworejo district, Central Java, found that most of the speakers stated that their parents had not been prepared to deal with menarche, due to busyness and ignorance of parents, and information that was not appropriate enough to be delivered (Wulandari 2008). In addition, based on the 2012 IDHS survey, $24.6 \%$ of female respondents did not discuss menstruation with other people before experiencing their first menstruation (SDKI, 2013). Children will find difficulty to go through this period, if they previously did not know and have never discussed it with their peers or mothers. Without adequate psychological information or information, menstruation will be a traumatic experience for adolescents (Shanbhag et al., 2012).

Knowledge of menstruation can affect children's attitudes and behavior towards the next menstruation. Increased knowledge about menstruation can be given at an earlier age so that it can improve healthy behavior during menarche and subsequent menstruation (Shanbhag et al., 2012). Health during menstruation must be considered because it is important and is a good opportunity for adolescents to understand their reproductive body and health better (Proverawati and Misaroh, 2017).

Lack of knowledge or ignorance about menarche especially menstruation does not only have an impact on aspects of reproductive health or psychological aspects. Shanbag et al. (2012) stated that $48.1 \%$ of female adolescents did not know that menstruation is related to pregnancy. Based on data from the Yogyakarta health office (2014), there was an increase in pregnancies among adolescence from $7.24 \%$ to $7.94 \%$ (Yogyakarta Health Office, 2015). Younger child in experiencing menarche can cause the risk of early pregnancy if the child is not provided with good knowledge about menarche and menstruation.

Media serves as a means to channel information from the sender of the message to the recipient of the message to think and pay attention to the learning process so that the learning process can occur (Daryanto, 2010). The printed media used in this learning process is in the form of comics and leaflets. Comics are illustrated stories with text which usually written in a word 
balloon that hangs up close to the head of the talking person. All text in comics is a sequence of relations between language and sequential images into one storyline (Waluyanto, 2005).

Whereas leaflet is a printed media that is generally used to convey information related to health education, leaflets in the form of paper containing material with any color printed on one or both sides and then folded, so that each fold is read as a separate page and the material does not pass the folds (Azhar, 2004).

The comic was chosen it is connected as something which related to things that are relaxed, light entertainment, funny, the pictures are striking and not too burdensome. Comics that contain serials of pictorial stories are popular with children. This study aimed to determine the effectiveness of comic as a learning media to enhance knowledge on menarche and menstruation among female students.

\section{SUBJECTS AND METHOD \\ 1. Study Design \\ This was a quasi-experiment with before and after study with control group design}

conducted at Muhammadiyah primary schools in Sagan and Kauman, Yogyakarta, Indonesia, from October to November 2016.

\section{Study Sample}

A sample of 90 female primary school students was selected for this study.

\section{Study Variables}

The dependent variable was knowledge of menarche and menstruation. The independent variables were comic and leaflet.

\section{Study instruments}

Comic and leaflet were made by researcher and validity of the instrument has been tested. The data were collected through questionnaire.

\section{Data analysis}

The data were analyzed by Mann-Whitney test.

\section{RESULTS}

Table 1 showed the results of knowledge on menarche before and after distribution of comic as learning media. Table 3 showed that knowledge on menarche after being given comic media (mean $=87.97 ; \mathrm{SD}=$ 7.19) was higher than before (mean $=67.68$; $\mathrm{SD}=10.20$ ) with $\mathrm{p}<0.001$.

Table 1. Knowledge on menarche before and after using comic as learning media

\begin{tabular}{lcccccc}
\hline \multicolumn{1}{c}{ Comic Media } & N & Minimum & Maximum & Mean & SD & p \\
\hline Pre-test & 44 & 40 & 80 & 67.68 & 10.20 & - \\
Post-test & 44 & 73 & 100 & 87.97 & 7.19 & - \\
Post-pre test & 44 & 7 & 60 & 22.50 & 11.75 & $<0.001$ \\
\hline
\end{tabular}

Table 2 showed that knowledge after treatment using leaflet as learning media before $($ mean $=63.82 ; \mathrm{SD}=7.66)$ with (mean=77.93; $\mathrm{SD}=8.30$ ) was higher than $\mathrm{p}<0.001$.

Table 2. Knowledge on menarche before and after using leaflet as learning media

\begin{tabular}{lcccccc}
\hline \multicolumn{1}{c}{ Media Leaflet } & N & Minimum & Maximum & Mean & SD & p \\
\hline Pretest & 46 & 47 & 80 & 63.82 & 7.66 & \\
Posttest & 46 & 60 & 93 & 77.93 & 8.30 & \\
Post-pre test & 46 & 7 & 60 & 22.00 & 7.52 & $<0.001$ \\
\hline
\end{tabular}

Table 3 showed the effectiveness of comic media compared to leaflet media in increasing knowledge before and after the media was given on the knowledge. Table 3 
showed that learning media using comic

media $($ mean $=38.04)$ with $\mathrm{p}=0.005$.

(mean $=53.30)$ was higher than leaflet

Table 3. The result of Mann-Whitney test of comic and leaflet learning media on increasing menarche and menstrual knowledge

\begin{tabular}{lccc}
\hline Variable & Mean & Delta & p \\
\hline Comic Media & 53.30 & 15.26 & 0.005 \\
Leaflet Media & 38.04 & & \\
\hline
\end{tabular}

DISCUSSION

1. Knowledge of menarche and menstruation before and after the distribution of comic learning media

The results showed that there was a signifycant difference in the results of the pretest and posttest in the provision of comic learning media or it could be said that there were differences in female grades after the comic media were given on knowledge of menarche and menstruation in the respondents. Factors that influenced the learning process are the instructor/ facilitator, students, material sources, and learning tools/ media. The choice of learning media can influence the learning process because it related to the delivery of information in the media, comics were a fun medium for children to learn, not just as a fiction but as visual communication media that can be applied as educational and informative educational tools (Dina, 2011).

Comics consisted of visual and verbal, but it was dominated by visual aspects because comics displayed images more than text. Image illustrations can help children to build imagination when reading the comics. The function of language in comics was not only to explain, complement, and deepen the understanding of the text but the language and images were directly integrated together to form a storyline (Waluyanto, 2005).

Providing health materials by using comics was an effort that aimed to improve healthy behavior through media that was appropriate for the children. Health educa- tion was a planned activity with the aim of changing someone's knowledge in taking actions related to health. Media used to deliver information on health education has an effect on learning processes (Cita, 2010). Giving material by using comic media during posttest showed an increase in knowledge about menarche and menstruation. It showed that learning with comic media has a good impact on the participants, which was increasing the knowledge about menarche and menstruation.

\section{Knowledge of menarche and mens- truation before and after distribu- tion of leaflet learning media}

The results showed that there were significant differences in the results of the pretest and posttest in giving leaflet learning media to the knowledge of menarche and menstruation, which indicated that the existence of health education by using leaflet media could have a good impact on students, which was increasing participants' knowledge in dealing with menarche and menstruation. Leaflets media was in the form of a piece of paper with any color printed on one or both sides then folded, as a single page. The results of this study was in line with Ambarwati et al. (2014), which stated that health education provided by effective leaflet media can increase knowledge. Leaflets were one of the printed media that were often used in the delivery of health education by health personnels. Leaflets were chosen because it was packaged briefly, densely, and clearly so that they can increase the interest of the respondents 
to read them. In addition, the advantages of leaflets were easily made, can contain information in the form of writing and several images so that the appearance was quite interesting, inexpensive, and flexible.

\section{The effectiveness of comic media compared to leaflet media in incre- asing knowledge about menarche and menstruation}

In this study, two research groups received different media. On the results of media effectiveness tests between comics and leaflets, there were significant differences in the average increase in knowledge after getting the media, the results of the analysis showed that comic media was more effecttive than leaflet media in conveying information about menarche and menstruation. Providing health materials using comics was an effort that aimed to improve healthy behavior through media that was appropriate for the age of the children. The media used in delivering material or information on health education has an effect on the conducive learning process. Comics can be an effective learning media to explain abstract concepts that required concrete objects on subjects (Waluyanto, 2005).

This research was in line with a study done by Handayani in 2010 which showed that learning by using comics was more effective than leaflet media (Handayani, 2010). Media comics as informative and educative media containing verbal with visual domination would help children to absorb knowledge and more easily to reach the level of knowledge of synthesis to evaluation. Worden and Flynn (1992) stated that an important step in the learning process was to make the message to be conveyed to the target, this can happen with the right media selection. In addition, the absorption of students can be influenced by the selection of learning media. The principles in improving memory in the basic process of learning and memory were influenced by visualization, interest or attention.

Comic media would improve memory by visualizing images because in considering the need for visualization, comic media can visualize abstract information to be more concrete. The use of comic media which consisted of visual and verbal aspects in which more dominating the visual aspects would help children to build imagination. Visualization of images and texts that made the storyline could balance the use of the right and left brain compared to the leaflets media which dominated by text. Leaflets media were commonly used by health professionals in delivering health promotions with cognitive effects but were not appropriate to provide emotional effects (Handayani, 2010).

Reading text in comics and the emergence of imagination and arousing emotions from colorful images were the advantages possessed by comics that were in accordance with the workings of the brain by balancing the use of left and right brains in accordance with the theory of split blind theory by Roger Sperry, the left and right brain which worked together would increase creativity and efficiency of the brain in absorbing and storing information. In addition, the use of comic media would attract students' reading interest because this media was an appropriate medium for childhood (Waluyanto, 2005).

\section{REFERENCES}

Ambarwati, Umaroh AK, Kurniawati F, Kuswandari TD, Darojah S (2014). Media leaflet, video dan pengetahuan siswa SD tentang bahaya merokok (Studi Pada Siswa SDN 78 Sabrang Lor Mojosongo Surakarta). Jurnal Kesehatan Masyarakat. 10(1): 7-13. https://doi.org/10.15294/kemas.v10- 
Journal of Health Promotion and Behavior (2018), 3(4): 257-262

https://doi.org/10.26911/thejhpb.2018.03.04.05

i1.3064.

Azhar A (2004). Media Pembelajaran. Jakarta: PT Raja Grafindo.

Badan Pusat Statistik (2015). Daerah Istimewa Yogyakarta dalam Angka 2015.

BKKBN (2012). SDKI. Survei Demografi dan Kesehatan Indonesia.

Cita M (2010). Komik sebagai media pembelajaran untuk memahami hubungan antar sudut. Universitas Sanata Dharma Yogyakarta.

Daryanto (2010). Media pembelajaran. Yogyakarta: Gaya Medika.

Dina I (2011). Ragam alat bantu media pembelajaran. Yogyakarta: Diva Press.

Dinas Kesehatan Yogyakarta (2015). Profil Kesehatan Tahun 2015 Kota Yogyakarta (Data Tahun 2014), Profil Kesehatan Tahun 2015 Kota Yogyakarta.

Flynn BS, Worden JK, Secker-Walker RH, Badger GJ, Geller BM, Costanza MC (1992). Prevention of cigarette smoking through mass media intervention and school programs. American Journal of Public Health. 82(6): 827-834.

Handayani S (2010). Perbandingan efektifitas pemberian informasi melalui media cerita bergambar (komik) versi BKKBN dengan Media Leaflet. Gester Jurnal Ilmu Kesehatan. 7(1): 482490.

Kartono K (2006). Psikologi Wanita Jilid I. Bandung: Mandar Maju.

Ozdemir F, Nazik, E, Pasinliolu T (2011). Determination of the motherly reactions to adolescents' experience of menarche-II. Journal of Pediatric and
Adolescent Gynecology. 24(1):21-4. doi: 10.1016/j.jpag.2010.06.004

Prawirohardjo S (2005) Ilmu Kebidanan. Jakarta: Yayasan Bina Pustaka.

Proverawati A, Misaroh S (2017). Menarche menstruasi pertama penuh makna, Yogyakarta: Nuha Medika.

Sally A (2005). Girl's experiences of menarche and menstruation. Journal of Reproductive and Infant Psychology. 23: 235-249.

SDKI (2013). Survei Demografi dan Kesehatan Indonesia 2012, Survei Demografi dan Kesehatan Indonesia.

Shanbhag D, D'Souza N, Shilpa R, Josephine $P$ (2012). Perceptions regarding menstruation and practices during menstrual cycles among high school going adolescent girls in resource limited settings around Bangalore city, Karnataka, India. International Journal of Collaborative Research on Internal Medicine \& Public Health. 4(7): 1353-1362.

Wahyudi (2001). Kesehatan Reproduksi Remaja. Jakarta: BKKBN.

Waluyanto HD (2005). Komik sebagai media komunikasi visual pembelajaran. Jurnal Desain Komunikasi Visual Nirmana.

WHO (2011). Health Profile. Available at: http://dinkes.jogjaprov.go.id.

Wiknjosastro H (2006). Ilmu Kebidanan, Edisi III. 3rd edn. Jakarta: YBP-SP.

Wulandari DS (2008). Peran orang tua terhadap remaja putri tentang menarche di kabupaten Purworejo Jawa Tengah. Tesis. Universitas Gadjah Mada. 